\title{
Laughing with and about Death? Werner Bergengruen's Philosophical and Literary Approaches
}

\author{
Albrecht Classen \\ The University of Arizona. Email: aclassen@arizona.edu
}

\begin{abstract}
Werner Bergengruen (d. 1964) was one of the most popular German authors from ca. 1930 to at least 1970, but his reputation has faded a lot, and there are only a few scholars today who are still engaged with his works, not to speak of the public. In his collection of novellas, Der Tod von Reval, however, Bergengruen developed a fascinating range of literary reflections on death as people in this Baltic city (Reval, today Tallinn) had experienced it throughout their history. Drawing extensively from medieval and early modern legendary accounts, this author translated in a highly meaningful manner the fundamental experience of death into an existentialist process profoundly informed by humanist values.
\end{abstract}

Keywords: Werner Bergengruen; Der Tod von Reval; life and death; historical narratives; Baltic literature

\section{Introduction}

As important as death is in and for life, hardly anyone can fully claim to understand death or to know how to deal with it constructively because all rationality and logic fail us in our epistemological, spiritual, or physical effort to come to terms with it. Death is one of the most arcane, elusive, incomprehensible phenomena in life which we like to ignore, dismiss, or forget about, and which nevertheless always reminds us of its immediate presence. We know that it had occurred when a person has died, but the rest falls into the sphere of religion. Artists, composers, architects, philosophers, poets, and writers throughout time and until today have engaged with this evanescent, yet concrete aspect, the end of our lives. The more they have provided us with illustrations, images, concepts, ideas, and arguments, however, the less do we seem to understand what is really going on in that critical final moment.

Should we thus abandon all efforts to comprehend this odd, possibly final moment since there could be, as most religions indicate, an afterlife promised by the various Scriptures? We would, however, then replace the hermeneutic approach with faith, believing in the promises by the New Testament, the Qur'an, or the Sanskrit texts. Those are, certainly, valuable for the faithful ones who are lucky enough to be embraced by hope, trust, confidence, and optimism regarding their future beyond death. What are the others supposed to do who do not simply follow a religion? Death proves to be a hermeneutic riddle for all people here on earth, so the best we can do to come to terms with it might be, as this paper will discuss in light of the novellas by a major twentiethcentury German author from the Balticum, Werner Bergengruen, would be to talk about death in many different modes and genres.

After all, we are humans, and we cannot simply ignore those who have gone before us because we will follow them for sure and will have to cross that ominous threshold ourselves one

(c) AesthetixMS 2021. This Open Access article is published under a Creative Commons Attribution Non-Commercial 4.0 International License (http://creativecommons.org/licenses/by-nc/4.o/), which permits non-commercial re-use, distribution, and reproduction in any medium, provided the original work is properly cited. For citation use the DOI. For commercial re-use, please contact editor@rupkatha.com. 
day. And in order to live with meaning and joy, we must accept death first of all as the one and only framework of all existence, providing us with a beginning and a perhaps only preliminary endpoint.

Most scientific fields can approach death only approximately, focusing on the physical aspects, observing the transition of the live body to the dead body, then its decomposition. The medical researcher can determine when the heartbeat has been silenced or when the brain waves have come to a stop, but is there any message to be detected within the dead body about the spirit which had fundamentally given meaning to the individual life? (Hamilton) The Humanities, by contrast, address death in a much more meaningful and insightful way because literature, the arts, and other related disciplines provide critical avenues for the engagement with death, mirroring emotions, sentiments, cultural conditions, and individual experiences. Death is an integral element of all human culture, of life itself, and the Humanities particularly prove to be at the forefront of investigating its meaning (Classen 2003; Classen 2020).

As Romedio Schmitz-Esser recently demonstrated, focusing on death as a cultural-historical phenomenon, allows us to gain profound and extensive insight into an entire world of rituals, ceremonies, religious practices, mentality, emotions, artistic responses, political strategies, etc. (2014/2016/2020). Even though we today tend to eliminate death from our normal discourse, previous centuries saw death through very different lenses, which explains why the study of death in the Middle Ages, for instance, proves to be so relevant and insightful (Feifel 1959; Noys 2005). In fact, medieval culture was apparently much more focused on death than later periods, considering the massive cult with graves, cemeteries, funeral procedures, liturgical masses for the dead, and the daily experience with death. The late Middle Ages could almost be called a world determined by death, if we consider the pervasive motif of the 'Dance of Death' (Gertsman 2010), the focus on Christ dying on the cross, the suffering from the Black Death from 1347 to 1351 and many times thereafter, the experience of other epidemics, and extensive wars (Classen, ed., 2016).

Many literary texts engaged intensively with the theme of death, whether William Langland's Piers Plowman (ca. 1370-1380), Johannes von Tepl's The Plowman (ca. 1400), or the anonymous's allegorical poem Des Teufels Netz (ca. 1415). Maybe the most famous and impressive artwork engaged with death, though often ignored even by the best art historians, was produced by Bernt Notke, the enormously evocative, intriguing, and remindful artistic tableau of the timeless power which death yields over people (Mänd and Albrecht, 2013):

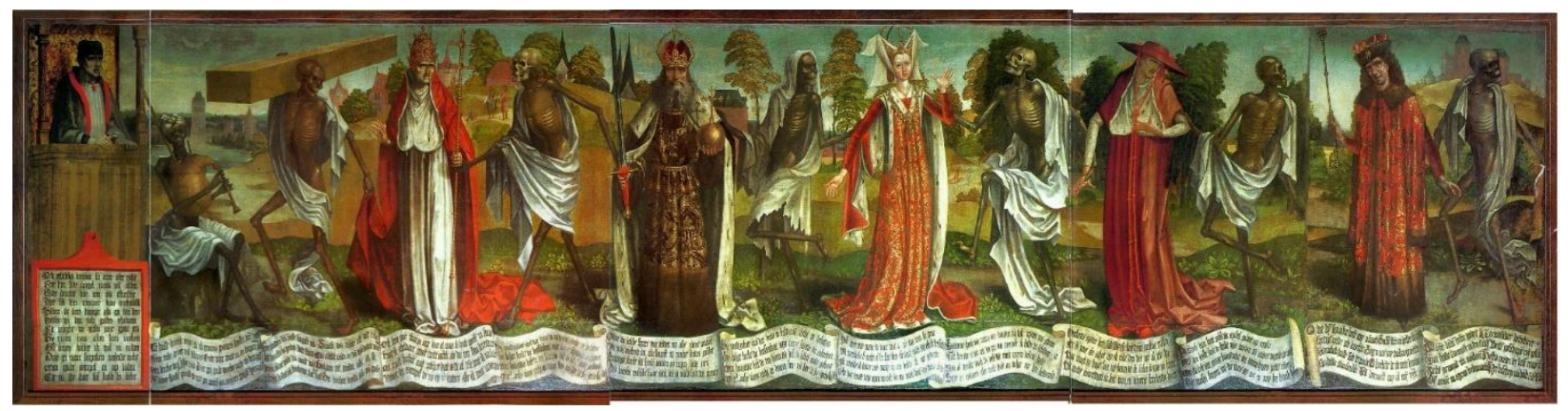

Bernt Notke: “Dance of Death,” Reval/Tallinn, St. Nicholas Church; http://www.dodedans.com/Eest.htm; public domain

The combination of forty-nine figures altogether, representing all social classes, genders, and age groups, with the skeleton figure of death appearing constantly among them, leaves an unforgettable impression, and the accompanying stanzas at the bottom of the huge canvas add most powerfully to this artwork. Notke and his workshop had originally created this master painting for St. Mary's in Lübeck in 1452, but the Reval (German name) citizens commissioned him to produce a copy. The 
original in Lübeck was destroyed during an American air raid in 1942, whereas the Tallinn painting (Estonian name) suffered badly during a Russian air raid in 1944, yet could be restored later (https://en.wikipedia.org/wiki/Danse_Macabre_(Notke)) (cf. Freytag, ed., 1993).

This paper does not intend to review the entire history of death and its cultural treatment once again, impossible by itself for one person, and it would repeat too much of what previous research has already accomplished. Instead, the focus will rest on the contribution by one major German writer from the middle of the twentieth century, Werner Bergengruen (1892-1964), who published not only numerous novels (ca. 12), poems, and essays, but also highly influential and popular short stories/novellas (ca. 200). In his collection under the title Der Tod von Reval (1939; The Death from Reval), Bergengruen created some of the most far-reaching reflections on death during the twentieth century as it is situated in the midst of all of human life. While he was born in Riga, today the capital of Latvia and located on the Baltic Sea, this anthology examines death as it was experienced in neighboring Tallinn, mostly in the late Middle Ages and the early modern age - Riga is today the capital of Latvia, and Tallinn is the capital of Estonia, ca. 6 hours north of it).

Even though Bergengruen has mostly disappeared from public view today, his anthology of short stories, apart from his many other works, certainly deserves to be remembered and to be reread. Most remarkably, he drew intensively from medieval and early modern history and literature (Classen, 2021, "From the Gesta Romanorum to Werner Bergengruen"), but he did not let the historical lens blind him to the timeless, hence highly topical issues that he wanted to examine from his own perspectives. As we will observe, one of the central strategies employed by Bergengruen consisted of drawing from many different medieval and post-medieval narratives, remodeling some of their themes and issues, and thus creating new, though certainly still timeless messages.

Modern scholarship, however, has mostly lost him out of sight, and so has the general readership. There are many reasons for this disappearance, such as his more conservative outlook, his refusal to engage specifically with the contemporary world in his publications, his seeming lack of interest in modern issues such as gender, environment, and race, and, perhaps worst of all for modern critics, the fact that he could survive quite effectively the Nazi regime - he went into a form of "internal exile" and kept publishing despite strong governmental limitations and even bans (Sobot 1962; Burckhardt 1968; Bänziger 1983; Kroll 1997).

Bergengruen's voice has always been meditative, spiritual, often religious, and conservative, so he simply seems to be inappropriate for the contemporary, more secular readership which might expect more dramatic, radical, social-critical approaches to the current issues. Recent efforts, however, have revealed, once again, how much this writer actually has to say to us, on a global level, offering profound insights into many different aspects of human life and death (Weiss 1987; Classen 2021).

In particular, Der Tod von Reval promises to shed new and old light on the fundamental confrontation between life and death, actually by removing the traditional barriers between both, indicating the true extent to which death is really integral to human existence. As the subtitle of Bergengruen's book signals, these novellas outline unusual approaches to death: Kuriose Geschichten aus einer alten Stadt (Curious Stories from an Old City), which encourage us to view death not as the grim reaper, but as an agent constantly working with us and through us, as a normal life force sustaining and threatening us at the same time. As the narrator emphasizes in the prologue, all old cities consist of an underworld of their own, their necropolis. The number of the dead always supersedes by far the number of the living, and the further back we go in history, the more we encounter former members of those cities. As long as memory is preserved, no one will 
ever really and fully die. The literary discourse as pursued by Bergengruen works specifically toward that goal, to preserve the memory of those who have passed away and have disappeared under their tombstones.

The narrator's focus is directed toward the vast number of deceased citizens of the previous urban communities, of whom gravestones, epitaphs, chapels, altars, and the cemeteries speak so silently and yet so vividly. As the narrator then underscores insightfully: "Die Lebenden sind ein Augenblick gleich der Gegenwart; die Toten aber sind die Unendlichkeit der Zeit und sind die Beständigen (9; The living are like a moment of the present; the dead, however, are the infinitude of time and are those who are constant. The today is the same for them as yesterday and tomorrow; they do not know the difference between the years, and they exist in a great calmness).

But dealing with death should not create melancholy and depression; even death has its own form of laughter (11). With the help of his novellas or short stories, Bergengruen intends to reveal the natural quality of death and its historical dimension, underscoring the fact that both dimensions, death and life, are intimately intertwined with each other. Those who are alive ought not to mourn excessively, they should not fear or despise the dead, and should not forget them either. It might be possible, as he suggests, that death is experienced differently in Mediterranean countries than in Baltic countries, especially because there, in the north, the transition from day to night, from summer to winter, would be less marked and not so sharp as in the south. Because of the cold weather in those countries, heavy alcohol matters much for everyone, which in turn blurs the difference between light and darkness, between cold and warm, between outside and inside (see Bergengruen's short story "Der Seeteufel," which I will discuss below). Bergengruen goes so far as to characterize the Baltic world as one of "Dämmerung" (12; dusk), fog, and snowfalls. Even the summers there are different than in the south because the sunsets more slowly. Altogether, as he observes monumentally: "Und mitten in allem Leben sind die Toten gegenwärtig" (12; And in the middle of all life the dead are present).

Although Der Tod von Reval enjoyed tremendous popularity, as documented by many reeditions - the last one appeared in Munich in 2006 - and a good handful of translations (Slovenian, 1964; Estonian, 1966; Italian, 1989; Latvian, 2000; Swedish, 2017, and now in English, 2021; data collected from Worldcat, online), research has not engaged extensively with Bergengruen's intriguing volume (for a few, almost rare exceptions, see Ritchie 1960; Kohnen 1994; Schmidt 1998). The poet transposes us regularly into distant history, but we are never far away from the actual events in the present time since past anecdotes are brought home to us in many curious ways. My intention here is not to summarize each and all of these novellas, or to discuss one all by itself to a great length. Since an English translation is about to appear in print, suffices it here to refer to the complete collection. This will then give us room to examine the collectively shared concept of death as an essential aspect of all life, as mirrored in all of the novellas.

\section{History and Death}

As the very first narrative, "The Account of the Life and Death of a Curious Person" already indicates, the poet carried out considerable research into the popular corpus of legendary accounts from the history of the city of Reval, now called Tallinn in its original Estonian. Here we are confronted with the history of the Duke of Croy who had served briefly the Russian Czar Peter the Great as the commander of his army besieging the city of Narva, which was then lost to the approaching Swedes, who took the defeated army as prisoners. The duke, whom we know as Charles Eugène de Croÿ, Duc de Croÿ (1651-1702), along with the other officers, was sent to Reval where he 
lived for two more years, when he suddenly died, obviously as a result of his excessive consumption of alcohol (for the history of the Baltic countries, see now Angermann and Brüggemann 2018; there is almost no recent research on the historical figure of this duke; but see, for the historical background, Sarauw 1881; Bushkovitch 2001). Although deeply indebted to many merchants and inn-keepers and enjoying a life of debauchery, the urban population had developed a kind of love relationship with this rambunctious man, so they all mourn his surprising passing away, though the outstanding debts cause many to worry. The duke cannot be properly buried for lack of money, and since not even the House of Croy back in France regards itself responsible, having long distanced itself from this drunkard and primitive person, the corpse remains unburied, being placed in nothing but a rough coffin and exposed to the elements.

The real story, however, does not concern so much the duke's biography but his afterlife because the body does not rot away; instead, it appears to become mummified, perhaps because of the huge amounts of alcohol deposited in him. The narrator then follows the destiny of this corpse over the next two hundred years, relates all kinds of curious anecdotes, and emphasizes how much this legendary figure emerged as a kind of mascot for the city of Reval and how the various administrative authorities tried to come to terms with this 'scandal' of an unburied person who held the rank of a Russian General Field Marshal. Finally, under Russian rule, the order is issued to dig a grave in one of the chapels of St. Nicholas where the mummy had rested for nearly two hundred years, which then ultimately removes the corpse from public view. This then also concludes the account, in which the dead assumed a greater significance than the living person. While all the duke's contemporaries certainly passed away, were buried, and thus disappeared, also from personal memories, the duke assumed and maintained his position in the public awareness and determined the city for so many years, and this over many generations.

Bergengruen created with this story a most unusual new literary genre, a blend of a chronicle with a biography and a novella. The reader learns much about the history of Reval, which witnessed much suffering, but also many good times, and all that is told through the lens of the dead man, the mummified Duc de Croy. We are invited to smile about this ironic development, considering that the duke was an undisciplined, crude, but also jolly and uncaring individual, in strong contrast to the honorable contemporary citizens, and to realize the relativity of all life because death is the only certainty in all existence.

\section{The Happy Homeless and Death}

On a more literary level, "Jakubsons Zuflucht" (Jakubson's Refuge) relates the story of a homeless man who once lived in the city of Reval. We do not learn much about him in biographical terms and are only informed that he was a popular figure due to his ability to play some music on his accordion, to whistle virtually any melody, and to entertain people in his simple ways. People enjoy telling each other anecdotes about this funny man. Parallel to him, who is introduced actually only fairly late, the narrator presents a wealthy old lady who is so miserly that she lives for rent somewhere in the impoverished suburb, completely separated from her family.

One day, she passes away, and her landlady helps to prepare the corpse for the funeral. At that moment, Jakubson enters the picture, but not as any of the mourners or family members; instead, he is running away from his companions whom he might have cheated out of their money during a card game. They are chasing him down the street and would have certainly beaten him up badly if he had not happened to notice an open window on the first floor facing the street. He quickly steps into the room, can thus hide from the persecutors, and is thus safe from a potentially 
grave danger. Looking around in the darkness, he notices that there are several bottles of strong alcohol (schnapps) that had been used for medical purposes. He quickly empties them, and when he feels tired enough, he discovers the bed where the dead old lady is resting. Jakubson, however, displays no hesitation, demonstrates his respect to the old woman, and lies down in the bed next to her, and quickly falls asleep.

As the narrator emphasizes, there was nothing one could do to help the deceased, and since the bed was so inviting, and since the homeless man had not slept in a real bed for such a long time, the presence of the dead next to him does not bother him at all. He was surprised to encounter the dead woman, but with all that alcohol in his body and the comfort of this bedroom, Jakubson reveals the healthiest attitude to death. He folds his hands, and then even touches the woman's hair as a good-bye salute. In other words, he observes the minimum of respect for the dead woman but he also looks out for his own needs and can thus enjoy a pleasant night, obviously well deserved after so many years of homelessness (8o-81).

Of course, he is discovered the next morning by the old woman's landlady and one of the deceased's male relatives, a public notary, and the scene almost explodes into a scandal because he is accused of having entered unlawfully the room and having committed necrophilia (82). However, he defends himself quite effectively, pointing out that he did not steal anything, that he did not behave inappropriately, that he quietly prayed for the old woman's soul, and, finally, that he had even asked for her permission to sleep next to her in that wonderful bed. Almost facetiously, he then comments: "Die gnädige Frau hat nichts dagegen gehabt" (85; The gentle woman was not opposed to it). Unfortunately, none of his arguments are of any use, although he even points out that he had been the last person who spent the night with her. He even dares to request a little souvenir (86), but the notary then, speechless out of utter fury, simply directs him out of the house, hoping that no rumors would spread in the city.

Jakubson's naïveté and uprightness prove to be disarming, and so he gets off this dangerous situation without being imprisoned or prosecuted. But the story does not conclude with this preliminary outcome. As part of the funeral rituals as they were practiced in old Reval - and are also practiced until today in many other cultures, especially in the case of a highly admired or respected person - the surviving family invites guests to a funeral dinner. To the surprise and dismay of everyone, Jakubson also appears and enjoys the meal, with none of the servants or attendees knowing what to do. Somehow, the secret of the scandal had been broken, so people now whisper amongst each other about it, but the festive dinner then takes its course, Jakubson serving himself well and operating without any false self-consciousness.

However, subsequently, he quickly disappears and re-surfaces only at the cemetery, where he also approaches the grave like all other mourners, throws a handful of soil into the grave, and then voices the astounding comment: "Auf Wiedersehen, gnädige Frau. Und ich bedanke mich auch" (91; Good-bye, gentle lady. And I also thank you). He also pretends to shed some tears to demonstrate a minimum degree of sorrowfulness and then disappears, whistling all the way back to the city, first using the choral funeral music, but then he quickly returns to his usual happy secular melodies. The lady's death did not face him, and yet he was thankful for her generosity after her death.

This homeless man appears to be the happiest person of them all, the one who honestly had a good reason to show his gratitude. This dead woman had saved him from his violent companions, she had provided him with plenty of alcohol, and then even with an excellent nightly rest next to her and all this despite the fact that she was already dead. Whereas throughout her life she had refused to show any kindness and generosity and had never granted Jakubson any alms, after she 
had passed away, this had become possible, even though only for this city bump. Hence, his final words at her grave were relatively honest since he truly meant what he said. The other participants in the funeral, on the one hand, displayed only formal gestures of mourning (90) and carried out the expected rituals, probably counting already the inheritance they hoped to receive. Jakubson, on the other hand, was the only one who had ever enjoyed kindness and practical help from this old woman, although she did not do it willingly, having passed away already when he needed her help the most.

As Bergengruen indicated with this story, life and death are intimately interlocking and need to be understood as parts of the same proverbial coin. The homeless man did not feel any anxiety about the dead person, and he calmly lied down next to her because he simply needed sleep. He certainly demonstrated his own kind of respect for the deceased, but he also did not forget to look out for himself, especially because he had found himself in a most dangerous situation. Without the old lady, so to speak, the other men would have certainly caught up with Jakubson and would have badly hurt or even killed him. In short, the dead saved the living, and the living paid true respect to the dead, touching her hair before he entered the bed for the night. As the homeless man demonstrated quite movingly, death is not something to feel shy about. The living have to keep living, and the dead can help them in that process. All of them can and should cooperate, which thus builds astounding ethical and spiritual bridges between both dimensions of all existence.

\section{Love, Marriage, and Death}

The story "Kaddri in der Wake" (Kaddri in the Fishing Hole) has more of the ring of the macabre, but it also concludes with strong feelings of love beyond death. Tönno is an impoverished eel fisher who has considerable difficulties to make enough money and also keeping his wife Kaddri under control concerning public decency. She is described as a loose woman who enjoys flirting with all kinds of men, and might even prostitute herself in the city. The marriage of these two people appears to be one of strife and conflicts, of domestic violence and lack of love, of mistrust and jealousy. Much of that belongs to the background of the story, with details only alluded to, whereas the central theme focuses on Tönno's surprising lack of success catching eel during one winter. At the same time, his wife seems to have disappeared, and this already for several days when the story sets in. Tönno is looking for her everywhere, but without finding her, until he finally returns to his workplace, the hole in the ice where his fishing gear is hanging in the water. To his big surprise, he has a hard time pulling it out of the water, and discovers his wife's corpse caught in it.

Apparently, she had habitually stolen eels from him, selling them on the market so she could purchase alcohol and flirt with men. One day, however, in her drunken stupor, she obviously tipped over, fell into the hole, and immediately died. Eels enjoy eating almost any kind of flesh, and the woman's corpse proved to be irresistible to them. Although Tönno is shocked about the horrible sight, he recognizes his unexpected great opportunity as a fisherman. For the next few days, he makes much money selling those eels caught on Kaddri's body, the best possible bait, so to speak. In his mind, he justifies the situation: "das war ja die allerhöchste Gerechtigkeit, daß Kaddri selbst, aus deren Schuld er hatte arm bleiben sollen, daß Kaddri selbst ihm den reichsten Fang und den reichsten Erlös schaffen mußte" (121; This was, after all, the highest justice that Kaddri herself, who had been responsible for his poverty, had to secure for him the richest catch and the richest profit).

However, the authorities soon find out what is going on with Tönno's new wealth, considering also the complete disappearance of his wife, and one night, the local bailiff Maddis 
confronts him, threatens him even with a severe punishment, but at the end, the two men reach an agreement. Maddis fines him for not having reported his wife's death, but he allows him to pay the fine in the form of eels, and since Tönno is a poor man, he grants him to use Kaddri's corpse for a little longer for the express purpose of catching more eel (130). The two men then part peacefully, and all seems to work out as arranged between them.

Yet, Tönno suddenly changes his mind. Reflecting on his dead wife, he now remembers that they both had once loved each other, that they had been married in the church, and that "sie zärtlich miteinander waren" (131; had been tender to each other). Realizing the sanctity of the human body, that is, the body of his own wife, he changes all of his plans, stops using the corpse as a bait for the eel, and carries the dead Kaddri home, where he carefully places her on the bed, covers her so that no human eye would ever see the eel-eaten flesh, that is, the flesh of a body which had granted him much joy, at least in the past (132). Tönno now can only see in this corpse the woman whom he had loved, and who is now dead. Consequently, the next morning he reports her passing away to the minister and arranges for the funeral.

We are certainly confronted with a rather macabre story about death, flesh-eating eel, and the dead woman serving as an ideal bait. The real focus, however, rests on the married couple and the long-lost love which used to exist between them. Although Tönno could certainly continue using her body to catch more eel and to earn an even better income, he remembers that this corpse is that of his own wife, and by now arranging the funeral, he brings her memory back to the community and lives up to the standards of all human societies to pay respect to the dead and to treat them in a dignified manner. Granted, Kaddri's body is already badly eaten up by the eel, but her widower finally makes sure that she is worthily buried, without anyone witnessing what had really happened to her. Through her death, he remembers the love which both had shared at some point. By ensuring her worthy burial, he eliminates all bad feelings about his wife's philandering, flirting, and prostitution, and thus reconstitutes her honorable identity both in his own mind and that of the community.

\section{Alcohol and Death}

\section{The Distillery of Life and Death}

Finally, in "Der Seeteufel" (The Sea Devil), the author employs a complex narrative strategy to lead his readers over to the story within the story, the metanarrative (Genette 1983; Haferland and Mecklenburg, ed., 1996). The frame narrative relates about an estate holder in Estonia who occupies himself in his long empty hours during Fall with the art of distillery, among other hobbies. His pride consists of drawing from the most uncommon plant matter to distill his alcoholic liquids, and the story sets in with him presenting a most unusual type of schnapps to two friends. Their reactions are as expected, they shudder, and one of them comments that this schnapps tastes like a drowned sailor, whereas the other characterizes its taste as like "die Kapitänin Holmberg" (97; the wife of Captain Holmberg).

He is then asked to relate the story, which thus creates the story within the story, as we are so well used to already, for example, from the Arabic One Thousand and One Nights or the panEuropean The Seven Wise Masters (nested stories; for a truly impressive list of similar cases in world literature, see https://en.wikipedia.org/wiki/Story_within_a_story). The sea captain Holmberg can never go on any voyage without his wife coming along who is completely bent on limiting the consumption of alcohol by the crew. One day, however, she shows symptoms of a sickness, but she still insists on accompanying her husband; otherwise, the discipline on the ship would suffer, as she 
argues. Tragically, she dies while the ship is on the high sea, and Holmberg is forced to carry out her last wish, to be buried in a barrel which then has to be filled up to the rim with alcohol to avoid the rotting of her body; she wants, after all, to be buried properly in the cemetery back home (71).

Indirectly, this also entailed that most of the schnapps provisions on board became very limited, obviously as intended by the captain's wife. However, the weather is rough, the sailors are all suffering, and one day, the captain notices that some of his crew members are drunken, once again. Soon, it turns out that they all have decided to drink from the barrel with the corpse inside of it, and the captain himself soon loses all inhibition and drinks the schnapps like everyone else. Since the crew had hated the dead woman because of her battle against their drinking habit, they celebrated the enjoyment of their drinking by cursing the deceased and laughing about her.

The irony of this internal story consists of the fact that the corpse proved to be entirely soaked by alcohol. Whereas the woman had been a devoted opponent to all alcohol, being abstinence in persona, now, after her death, she appeared to have compensated for all this denial during her life, actually being more drunk than everyone else on the ship. As all the sailors realized, it would have been entirely sufficient if the corpse had been thinly covered with alcohol in order to keep it fresh and free from rotting. Her instructions, however, had been a vicious strategy to deny the crew the desired alcohol: "Das war bloß ihre Bosheit, daß das ganze Faß vollgeschüttet werden mußte" (74; It had been nothing but her evilness that the entire barrel had to be filled with [schnapps]; for medieval treatments of the corpse with alcohol for specific purposes, see SchmitzEsser 2014/2016/2020, pp. 225, 281-82, 300).

In the conclusion, the narrator comments, expressing his astonishment: "Aber wurde wohl je einer abgeschiedenen Seele ein wunderlicheres Trankopfer dargebracht als dem schnapsfeindlichen Seeteufel“ (74; But has ever a deceased soul received a more curious libation than the sea devil who hated schnapps?). No one on the ship had any respect for this woman; the entire male crew hated her, and hence the moniker for her, the Sea Devil. But after her death, her body took in more alcohol than anyone among them had ever drunk in a short period of time. The radical proponent of abstinence thus ended up as the worst alcoholic, so to speak. Nevertheless, once the ship had returned to Reval, the dead woman was buried at the cemetery, as she had requested. Her husband, however, then turned into a heavy drinker, lost his self-control, then his job, and soon ended up as a simple harbor worker until his early death.

Only then does the main narrator return to his own account and reveals what his schnapps had been distilled from seaweed, which could have been toxic, as one of the guests, a medical doctor, notes with horror. The other guest, a minister, calms him down, however, referring them all to the mercy of God even in such cases, and asks for a second glass of this devilish distilled liquor, which he then appropriately calls "Seeteufel" (75; Sea Devil). As this and the other novellas confirm, life and death are almost one and the same; all life will join death, and thus death proves to be a friend and not an enemy.

\section{Bergengruen's Epilogue}

\section{Death as a Friend and as Consolation}

As the narrator emphasizes in the epilogue, "Der Tod ist ein großer Trost" (175; Death is a great consolation). Facing death as the omnipresent entity and accepting it as such, would dissolve all fear because death becomes familiar, both in that Nordic city, Reval/Tallinn, as well as in Bergengruen's short stories. As the painting by Bernt Notke confirms, death is the essential 
component within and through life, constituting life by taking it away, being paradoxical and irrational, but all present and timeless. For the narrator, and thus also for Bergengruen, as far as we can tell, the only reasonable approach would hence be to embrace death and to extend one's love to it because death grants peace and tranquility (176).

In a virtually monumental and universal gesture, the author then concludes his collection with the deeply religious (Christian and other) insight, a prayer attributed to 2 Esdras, an apocryphal text outside of the Vulgate as compiled by Jerome: "Requiem aeternam dona eis, Dominae. Et lux perpetua luceat eis" (176; Grant eternal rest unto them, O Lord, and let light perpetual illuminate them). This universal prayer for the dead, used both by the Catholics and the Protestants and which had reappeared since the ninth century, would appeal to all people across the world, and indeed establishes a direct connection between this and the other world (https://en.wikipedia.org/wiki/Eternal_Rest; see also https://en.wikipedia.org/wiki/2_Esdras).

Death does not mean the endpoint of life; it represents simply the other side of the same room, only separated by a door, and those who are willing to drink some strongly distilled liquor, as many people in Bergengruen's novellas do, are somehow one step closer to the other side and lose all fear. Correspondingly, the narrator finally mentions that he needs to sprinkle a few drops from the bottle out into the night as a sacrifice "für die noch Unruhigen, ein Gedächtnis für die, welche zu ihrer Ruhe gekommen sind" (176; for those who are still restless; a mindful memory of those who have found their peace). With the 'restless,' the author means all people here in this life; and those who have found their peace are the dead.

\section{Conclusion}

There is always a continual transition, from here to there, and there is no reason to despair. As the entire collection insinuates, death is, of course, unavoidable, and people throughout time have responded to it in many different ways, more often than not in a rather loving, kind, nostalgic, but also curious and irrational manner. It behooves us, as Bergengruen suggests, to embrace death, to smile about and with it, and to recognize that the living and the dead are all members of the same community. What matters so critically, as the author formulates in many different approaches, is to lay all fear of death to rest, to recognize it as part of life, and thus to celebrate memory because the future is grounded in the past (Classen 2019, "The Past as the Key"; Classen 2020, "The Amazon Rainforest").

Of course, the human mind has a very hard time wrapping its head around the phenomenon of death, and neither the medical nor the physical sciences can assist us much in that endeavor. But the literary voice lends itself well as a critical guide from life to death, or, as Dante Alighieri would have said it in light of his Divina Commedia (ca. 1320), from human existence to Hell, from there to Purgatory and then on to Paradise. Der Tod von Reval makes death to a companion, maybe even to a friend who illuminates the opaque other dimension, inviting us to smile about the curious perspectives people have regularly assumed throughout time regarding the other side of life.

It is maybe even more than serendipitous that I completed these reflections on Werner Bergengruen's deeply insightful collection of tales on the eve of Easter, 2021. His anthology offers deep messages for all people here on earth, irrespective of any religious orientation, inviting the audience not to overdramatize the end of life, to smile about curious approaches to the process of dying and the funeral, and to consider death as an important vehicle to discuss the meaning of life in the first place. Death is not to be feared; death is part of all existence, and it illuminates in a glorious way the beauty and happiness of this life in its material and spiritual dimension, as the 
Plowman in Johannes von Tepl's eponymous dialogue poem The Plowman of Bohemia (ca. 140o) formulates at the end in his brave and uplifting argument against contemptuous death (ch. 25) (Classen 2021, "The Plowman"), where he glorifies the beauty and excellence of the human organs, all God's own creations.

Both as a writer and a cultural historian, Bergengruen emerges as a fascinating builder of literary and historical bridges between the past (the Middle Ages) and the present. While he utilized many medieval historical, religious, and literary accounts for his various novels and short stories (e.g., Das Buch Rodenstein [1927; expanded in 1951; The Book of Rodenstein; Herzog Karl der Kühne [1930; revised in 1943; Duke Charles the Bold], here in Der Tod von Reval he drew from a variety of local legends dating from the past, and also from the medieval art in the city, the famous Dance of Death painting by Bernd Notke (see above). Not by accident, he included two short excerpts from the verse stanzas underneath the individual panels in the St. Nicholas Church, still present there until today, which read, in late medieval Middle Low German:

To dessen danße rope ik alghemene:

pawers, kaiser unde alle creaturen,

arme, ryke, grote unde klene! (10)

[I call up everyone to this dance,

peasants, emperor, and all creatures,

poor, rich, great and small.]

And:

Se ik vore efte achter my,

ik vole den dot my alle tyt by (10)

[Whenever I look in front or behind me,

I follow death all the time.]

Bergengruen urges us to put melancholy aside, to dismiss fear of death, and to laugh about and with it, as the novellas invite us to do (11), such as in "Jakubson's Refuge" or in "Schneider and his Obelisk" and "The Head" (here not discussed). As much as we as human beings are supposed to reach out to the divinity and to become familiar with it, as much we ought to do the same with death. Life, death, and God all belong intimately together. Bergengruen's Der Tod von Reval thus proves to be a literary approach to death that could not be more timeless and meaningful, and so for us in the twenty-first century as well. Insofar as the author regularly drew from medieval and early modern historical accounts, he suggested to his contemporary audience that they could learn much from the past in order to come to terms with their own future, beyond their death. 


\section{References}

Angermann, Norbert and Karsten Brüggemann. Geschichte der baltischen Länder (Stuttgart: Philipp Reclam jun., 2018).

Bänziger, Hans. Werner Bergengruen. Weg und Werk. 4th rev. ed. Bern: Francke, 1983.

Werner Bergengruen, Der Tod von Reval: Kuriose Geschichten aus einer alten Stadt (1939; Frankfurt a. M. and Hamburg: Fischer Bücherei, 1956). An English translation by Albrecht Classen is forthcoming with Cambridge Scholars Publishing, 2021.

Burckhardt, Carl J. Über Werner Bergengruen, mit vollständiger Bibliographie, fünf Porträtskizzen und Lebenslauf. Zürich: Verlag der Arche, 1968.

Bushkovitch, Paul, Peter the Great: The Struggle for Power, 1671-1725 (Cambridge, England: Cambridge University Press, 2001).

Classen, Albrecht. "From the Gesta Romanorum to Werner Bergengruen: Literary Mirrors for Princes from the Late Middle Ages to the Twentieth Century," to appear in Amsterdamer Beiträge zur älteren Germanistik.

Classen, Albrecht. "Werner Bergengruen," Literary Encyclopedia, online, first published on Jan. 25, 2021 (https://www.litencyc.com/php/speople.php?rec=true\&UID=14708).

Classen, Albrecht. "Johannes von Tepl, Der Ackermann aus Böhmen," Literary Encyclopedia, online, Feb. 4, 2021; https://www.litencyc.com/php/speople.php?rec=true\&UID=5805.

Classen, Albrecht. "A Conversation with Dr. Albrecht Classen on "Diseases, Death and Disaster during the Medieval Period," Interview with Pragati Das. The Golden Line Magazine 3.1 (2020), ed. by the Department of English Bhatter College, Dantan (West Bengal, India)

http://goldenline.bhattercollege.ac.in/v3n1/.

Classen, Albrecht. "The Amazon Rainforest of Pre-Modern Literature: Ethics, Values, and Ideals from the Past for our Future. With a Focus on Aristotle and Heinrich Kaufringer," Humanities Open Access 9(1). 4 (2020), published on Dec. 24, 2019, online at: file://C:/Users/aclassen/Downloads/humanities-o9oooo4.pdf.

Classen, Albrecht. "The Past as the Key for the Future: Reflections on an Ancient Question. What Does (Medieval) Literature Mean Today in the Twenty-First Century?," Athens Journal of Philology 6.3 (2019): 147-70; online at: https://www.athensjournals.gr/philology/2019-6-3-1-Classen.pdf

Classen, Albrecht, ed. Death in the Middle Ages and Early Modern Times: The Material and Spiritual Conditions of the Culture of Death. Fundamentals of Medieval and Early Modern Culture, 16 (Berlin and Boston: Walter de Gruyter, 2016).

Classen, Albrecht. "Death Rituals and Manhood in the Middle High German Poems The Lament, Johannes von Tepl's The Plowman, and Heinrich Wittenwiler's Ring," Grief and Gender: 70o-17oo. Ed. by Jennifer C. Vaught (New York: Palgrave, 2003), 33-47.

Feifel, Herman. The Meaning of Death (New York: Blakiston Division, McGraw-Hill, 1959).

Freytag, Hartmut, ed. Der Totentanz der Marienkirche in Lübeck und der Nikolaikirche in Reval (Tallinn): Edition, Kommentar, Interpretation, Rezeption. Niederdeutsche Studien, 39 (Cologne, Weimar, and Vienna: Böhlau, 1993).

Genette, Gérard. Nouveau discours du récit. Poétique (Paris: Ed. du Seuil, 1983).

Gertsman, Elina. The Dance of Death in the Middle Ages: Image, Text, Performance. Studies in the Visual Cultures of the Middle Ages, 3 (Turnhout: Brepols, 2010). 
Haferland, Harald and Michael Mecklenburg, ed. Erzählungen in Erzählungen: Phänome der Narration in Mittelalter und Früher Neuzeit. Forschungen zur Geschichte der älteren deutschen Literatur, 19 (Munich: Wilhelm Fink, 1996).

Hamilton, Allan J. The Scalpel and the Soul: Encounters with Surgery, the Supernatural, and the Healing Power of Hope (New York: Jeremy P. Tarcher/Putnam, 2008)

Kohnen, Joseph. "Der Tod im Tod von Reval,“ Brücken schlagen ... "weit draußen auf eigenen Füßen”: Festschrift für Fernand Hoffmann, ed. Joseph Kohnen (Frankfurt a. M., Berlin, et al.: Peter Lang, 1994), $113-34$.

Kroll, Frank-Lothar, “Der Lebensweg,” Dichtung als Kulturvermittlung: Der Schriftsteller Werner Bergengruen. Beiträge für Unterricht und Weiterbildung. Schriftenreihe Haus der Heimat des Landes Baden-Württemberg. Die Deutschen und ihre Nachbarn im Osten. Geschichte und Gegenwart, 7 (Filderstadt: Weinmann, 1997), 12-23.

Art, Cult and Patronage: die visuelle Kultur im Ostseeraum zur Zeit Bernt Notkes, ed. Anu Mänd and Uwe Albrecht (Kiel: Ludwig, 2013).

Noys, Benjamin. The Culture of Death (Oxford and New York: Berg, 2005).

Ritchie, J. M. "Allegory and Mannerism in Werner Bergengruen and his Der Tod von Reval,"German Life and Letters 13.4 (1960): 248-54.

Sarauw, Christian von. Die Feldzüge Karl's XII: ein quellenmässiger Beitrag zur Kriegsgeschichte und Kabinetspolitik Europa's im XVIII. Jahrhundert: Mit einer Uebersichtskarte des nordischen Kriegstheaters und sechs lithographischen Tafeln (Leipzig: Schlicke, 1881).

Schmidt, Christoph. “Bergengruens ‘Tod von Reval’ aus historischer Sicht,” Journal of Baltic Studies 29 (1998): 315-25.

Schmitz-Esser, Romedio, Der Leichnam im Mittelalter: Einbalsamierung, Verbrennund und die kulturelle Konstruktion des toten Körpers, as The Corpse in the Middle Ages: Embalming, Cremation, and the Cultural Construction of the Dead Body (orig. 2014, re-published 2016) (Turnhout: Harvey Miller Publishers, Brepols, 2020).

Sobot, Elisabeth. Das Menschenbild bei Bergengruen: Einführung in das Werk des Dichters. Munich: Nymphenburger Verlagshandlung," 1962.

Weiss, Gerhard H. "Werner Bergengruen," German Fiction Writers, 1914-1945, ed. James Hardin. Dictionary of Literary Biography, 56. Detroit, MI: Thomson Gale, 1987, 27-38. 